\title{
Critical Study
}

Etude Critique

\section{David Wallace}

\section{(2) OpenEdition}

\section{Journals}

Electronic version

URL: https://journals.openedition.org/etudesirlandaises/3217

DOI: 10.4000/etudesirlandaises.3217

ISSN: 2259-8863

Publisher

Presses universitaires de Caen

\section{Printed version}

Date of publication: 30 October 2012

ISBN: 978-7535-2158-2

ISSN: 0183-973X

\section{Electronic reference}

David Wallace, "Critical Study", Études irlandaises [Online], 37-2 | 2012, Online since 30 October 2014, connection on 31 July 2022. URL: http://journals.openedition.org/etudesirlandaises/3217 ; DOI: https://doi.org/10.4000/etudesirlandaises.3217

This text was automatically generated on 31 July 2022.

\section{(c) (i) 8 (2)}

Creative Commons - Attribution-NonCommercial-ShareAlike 4.0 International - CC BY-NC-SA 4.0 https://creativecommons.org/licenses/by-nc-sa/4.0/ 


\title{
Critical Study
}

\author{
Etude Critique
}

David Wallace

\section{REFERENCES}

Richard ALlen CAVE, Collaborations - Ninette de Valois and William Butler Yeats, London, Dance Books Ltd, ISBN: 978-1-85273-143-4.

Victoria O'BRIEN, A History of Irish Ballet From 1927 to 1963, Bern: Peter Lang, ISBN

978-3-03911-873-1.

1 Two recent publications concerned with the development of ballet and theatre dance in Ireland have begun to address the largely unrecorded history of these disciplines in Ireland. Collaborations by Richard Allan Cave is concerned with the collaborative relationship between W.B Yeats and Ninette de Valois, while A History of Irish Ballet from 1927-1963 by Victoria O'Brien concerns itself with documenting a more general history of how a ballet school developed from the collaborative efforts of Yeats and de Valois. Both books take as their focal point the setting up of the Abbey School of Ballet and the relationship between W.B Yeats, founder of the Abbey Theatre and Ninette de Valois, an Irishwoman who founded what was to become the Royal Ballet. However, once this point is made, the books diverge and begin to trace very different aspects of the role of de Valois in the theatre life of Ireland at this time.

2 Richard Allan Cave's Collaborations presents a fascinating and impeccably researched account of the toils and tribulations associated with the creation and staging of Yeats's dance plays. Inspired by the Japanese Noh plays of the turn of the last century, Yeats sought to create a type of dance-action hybrid with a distinctly Celtic overtone. According to Cave, who interviewed de Valois on numerous occasions, de Valois represented for Yeats his ideal embodiment of the dance and was a logical choice for the creation and in some cases re-creation or re-staging of the choreography for these plays. 
3 De Valois had been working with her cousin Terence Gray at the Cambridge Festival and Yeats had seen her success with his and other theatrical productions and wanted to employ her services to establish a ballet school at The Abbey, its primary raison d'etre being to provide dancers for the dance plays that Yeats had composed and was composing or revising at this time. Cave goes on to trace the stylistic development of de Valois through her time with Gray at Cambridge and illustrates this development through a series of photographs taken of the productions she danced in and choreographed. The style of choreography de Valois began to explore at Cambridge had a direct impact on the style she would later create at The Abbey for Yeats; her use of mask and mimetic movement stemmed from both her influences and the Noh style of theatre Yeats was eager to explore. Throughout the chapters in the first part of this study a picture is steadily built of an artist and an artistic union which was to prove one of the most rewarding for theatre in Ireland during the time period and indeed for both the collaborators involved.

$4 \quad$ The second part of the study looks at each of the four dance-plays in detail, exploring their genesis, inspirations and the influence de Valois had on the subsequent revisions of the plays already written. Rigorous and detailed analyses inform these chapters, with the role of de Valois always held as the focal point. It is fascinating to see just how much influence de Valois came to have on Yeats; this is highlighted by his own words depicting his upset when he learned that she was leaving her post at the Abbey to pursue greater things in Britain. The first play discussed is the first one de Valois worked on, although it is not the first time Fighting The Waves (The Only Jealousy of Emer) had been staged. This play, according to Cave, underwent many incarnations and revisions throughout Yeats's career and it seems the version with de Valois was the most fruitful for him. Parallels are drawn with An Baile's Strand, on which de Valois had worked with her cousin Terence Gray at Cambridge and in which Yeats had been so impressed with her interpretation of the dance sequences. Fighting The Waves seems to have been Yeats's most problematic dance play - the inclusion of the mask creating unprecedented issues for the writer, but his collaboration with de Valois was, for him, his most successful. The play had a successful run at the Abbey but was not without its criticism. The Dreaming of the Bones was the next dance drama to be staged at the Abbey in 1931. At this point Nesta Brooking had taken over the running of the dance school and while de Valois choreographed the role for the dancer in the play, Brooking danced in the production. This play for dancers had been composed in conjunction with the Easter Rising in 1916 and the atmosphere of the play reflects this context. Cave goes on to analyse in wonderful detail the staging and the performances of The Dreaming of the Bones paying particular attention to context, musical accompaniment, costume, annotations in manuscripts and performance directions - in other words the performance aspects of the work. At The Hawk's Well provided an opportunity for de Valois to re-choreograph the only one of the dance plays to have been choreographed before this collaboration began. Yeats had worked with the dancer Michio Ito in 1916, creating the role of the Hawk. Cave notes a departure here in the style required for the dance plays as distinct from the previous two plays de Valois had worked on - the dance sequence is much longer and requires a number of critical changes in mood and tempo. The role is a study in oneness with the part to be played. The dancer must be totally absorbed in the role, a difficult task considering the dancer does not move until half way through the dramatic action but is required to remain still, shrouded in a cloak. De Valois saw the challenge of her roles in the dance plays very much in this way 
- achieving this oneness was her goal. The final collaboration was to be The King of The Great Clock Tower. Yeats composed this play especially for de Valois and her performance in it at the Abbey in 1934 was to be her last in Ireland. Cave presents a parallel with this play and the Oscar Wilde Salome, in which de Valois had choreographed the famous dance sequence on numerous occasions. Cave goes on to analyse the play in great detail, helped by the large amount of material available on this production and gives us a poignant account of the production and composition of the play.

5 This book addresses a long ignored collaborative relationship, presenting the work created by these two artists as the main focal point of the book while exploring the more personal relationship between the two with sensitivity and a sense of awe. The many plates of the dancers, costumes, sets, and de Valois herself in performance provide a rich support to the text and help to paint a clear picture of the type of dance form that de Valois worked with during this period; it also attests to the type of theatre being developed in Ireland at this time. Collaborations provides a thorough and at times touchingly personal account of the work these two giants of the theatre world achieved together. One cannot help but be moved by the tragic, mournful atmosphere of Yeats words about the loss of his dancer-muse to her success in London. His final play The Death of Cuchulainn was never performed in his lifetime. Perhaps all of these plays need to be revisited and revivals attempted. Even without the exact choreography of de Valois it would be a fascinating project to stage these plays as they were performed in the days of the Abbey School of Dance. What an achievement Cave has documented here and it is a sobering thought that in Ireland in the 1920s and 1930s productions of an international level both in an emotional and experimental sense were mounted and were largely successful.

6 As mentioned earlier, A History of Irish Ballet 1927-1963 by Victoria O'Brien, takes as its starting point the collaboration between de Valois and Yeats in a more general historical way. The history that O'Brien refers to is indeed a history of ballet, but not one of ballet in Ireland as she curiously ignores all other developments in ballet outside Dublin during her time-period; it is a very thorough and well-researched account of ballet/dance history in Dublin. O'Brien provides a linear view of her subjects and highlights this through her tracing of the influence of de Valois and her students on ballet and by extension theatre dance in Ireland. The book proposes de Valois' influence on the development of dance in Ireland in a much more direct way then Cave does, Cave being more concerned with the collaborative relationship between his two subjects. It is noted in both publications that de Valois was only resident in Ireland for about 7 weeks per year, while it was left up to her students, Sara Payne followed by Nesta Brooking, to organise and teach the dance classes and performances for the rest of the year. O'Brien traces the ballet history, as she sees it, from the pupils of Brooking and Payne through to the development of the various companies in Dublin - Irish Ballet Club, The Abbey School of Ballet (as a private school), the Sara Payne Company and the National Ballet Company.

7 An unfortunate leitmotif in the text is the tone O'Brien takes with the developments that occur outside Dublin, in particular dismissing the achievements of Joan Denise Moriarty, a student of Marie Rambert and director of the first professional company in Ireland, her students and many collaborators. In fact the text erroneously indicates that Moriarty may have plagiarised some or all of the choreography for two of her early 
ballets: Rosamunde and An Coitin Dearg and suggests that Moriarty routinely assumed authorship of ballets produced by other choreographers: Cepta Cullen and Puck Fair is cited as an example. The evidence, however, paints a very different picture. It refutes these claims, proving that Sara Payne based the ballet Fair Rosamunde on a totally different scenario to the one produced by Moriarty: Rosamunde, while the music for Moriarty's version of Coitin was by Aloys Fleischmann, a different composer to Cullen's version, while the version Cullen was working on never actually materialised. The issues surrounding Puck Fair are a little more complicated as the Moriarty archives were not available to O'Brien, these contain correspondence between the two women with Cullen advising Moriarty to mount her own version due to casting ${ }^{1}$. However a study of the 1948 and 1953 Cork Ballet Company programmes shows that Moriarty does in fact acknowledge the Dublin version; these were readily available for O'Brien to consult. It is however very difficult to say with any certainty if any of the movement vocabulary from Cullen's version ended up in the Moriarty one as no notes from either production are known to exist.

Also called into question is Moriarty's competence as both an Irish dancer and ballet dancer. Moriarty was a champion Irish step-dancer, winning the Irish Step Dance Championship of England in the $1931^{2}$, and her pedigree as a ballet dancer has already been discussed. The re-publication of a biased and obviously contentious letter from Patricia Ryan as proof of Moriarty's proposed incompetence is not, in my opinion, in good taste; historically it is interesting in that it highlights the type of struggles Moriarty must have had to deal with if her collaborator had these opinions of her ability.

Other smaller companies are documented in an attempt to flesh out the history of ballet in Dublin to the detriment of the companies based in Cork: The Cork Ballet Company (1947-1993) and Irish Theatre Ballet (1959-1964). There is some confusion in the general facts of the development of the professional companies in Ireland. Irish Theatre Ballet was in fact the first professional ballet company in Ireland, a company that had state funding, full-time professional dancers and musicians and a company that staged many of the standard rep ballets as well as commissioning new work from eminent Irish and Anglo-Irish composers of the day, touring and establishing education and outreach projects in schools and localities from 1959-1964 ${ }^{3}$. This company gets little coverage and is incorrectly labelled a semi-professional company. The account that follows of the formation, and subsequent disbanding of National Ballet Company (1959-1963) focuses primarily on the assumed personal reasons for its demise rather than the financial and administrative issues in the company, present from before the merger with Irish Theatre Ballet in 1963, and the resulting inability to attract audiences. The archives of AJ Potter, a collaborator with Ryan on three ballets and a director of the National Ballet Company, shed much light on this subject and seem not to have been consulted in the research for this chapter ${ }^{4}$.

O'Brien makes interesting points about the first attempts to fuse Irish dance and ballet steps by Sara Payne and her own company. Perhaps further research into this area would yield a greater understanding of just how successful and how influential this hybrid was.

11 One of the most frustrating omissions in the text is that of context. The author does not provide any social or political context with which one can fully assess the incredible achievements of all of those involved in the attempts to create a national tradition of 
ballet in Ireland. This is somewhat excused in the appendix. However, placing the artist in the social and political contexts in which they work surely should have formed a central point in the discussion of the ballet companies and individuals involved in the creation of the tradition. The title of the book intimates a more thorough study of the art form, while the reality betrays a bias that mars the overall effect of the text. While this book is a very useful history of ballet in Dublin it is not, as the title states, a history of ballet in Ireland.

These two books represent a resurgence of interest in the study of dance and particularly theatre dance in Ireland and its origins. The importance of these studies in the pantheon of dance literature should not be underestimated. Irish dance and the development of ballet in Ireland have an important and relevant place in the dance history of our world. The most exciting consequence of these publications is that, now, studying and assessing the ballet history of Ireland has been made a little easier by having the origins of the dance in print. Further study is needed to fully assess the influence of these artists and the huge body of works left behind, now largely unperformed.

\section{NOTES}

1. Letter from Cepta Cullen to Moriarty, 9 March 1948, Moriarty Archive, Cork City Library.

2. Ruth Fleischmann (ed.), Joan Denise Moriarty, Founder of Irish National Ballet, Cork, Mercier Press, 1998.

3. Ibid.

4. R. Fleischmann brought this point to my attention. Further discussion can be found in: Patrick Zuk, A.J. Potter (1918-1980), University of Durham Ph.D. thesis, 2008, Chapter 5 p. 56-60. 